\title{
KAJIAN PENANDA SOSIOKULTURAL PADA CERITA RAKYAT PASER DAN BERAU KARYA SYAHIDIN DKK. UNTUK PENGEMBANGAN MATERI AJAR KRITIK SASTRA
}

\section{THE STUDY OF SOCIOCULTURAL MAKERS IN CERITA RAKYAT PASER DAN BERAU WRITTEN BY SYAHIDIN ET AL FOR THE DEVELOPMENT OF LITERARY CRITICISM TEACHING MATERIAL}

\author{
Indah Ika Ratnawati ${ }^{1 *}$, Ari Musdolifah ${ }^{2}$, Maryatin $^{3}$ \\ Pendidikan Bahasa dan Sastra Indonesia, Universitas Balikpapan, Indonesia ${ }^{1,2,3}$ \\ $\underline{\text { indah.ika@uniba-bpn-ac.id }}^{1}$, ary.musdolifah@uniba-bpn.ac.id ${ }^{2}, \underline{\text { maryatin @ uniba- }}$ \\ bpn.ac.id ${ }^{3}$ \\ *penulis korespondensi
}

\begin{tabular}{ll}
\hline Info Artikel & ABSTRAK \\
\hline Sejarah artikel: & Tujuan penelitian ini adalah mendeskripsikan penanda sosiokultural dalam \\
Diterima: & buku Cerita Rakyat Paser dan Berau karya Syahidin, dkk., dan \\
10 November 2019 & mendeskripsikan pengembangan materi ajar kritik sastra melalui \\
Direvisi: & pendekatan sosiokultural. Penelitian ini adalah penelitian pengembangan \\
21 Desember 2019 & dengan menggunakan desain educational research and development \\
Disetujui: & (R\&D). Hasil penelitian ini adalah penanda yang terdapat dalam 20 cerita \\
14 Januari 2020 & rakyat Paser dan 17 cerita rakyat Berau, yaitu cara berpikir rasional, sikap \\
& bijaksana, kebiasaan hidup gotong royong, sikap pantang menyerah, sikap \\
Kata kunci: & tanggung jawab, sikap tolong menolong, kebiasaan hidup berburu, cara \\
Cerita rakyat, & berpikir percaya takhayul, sikap saling menghargai, sikap bijaksana, cara \\
sosiokultural, semiotik & berpikir tidak rasional, sikap gagah, sikap menghormati, sikap saling \\
& menyayangi, sikap musyawarah, sikap tabah dan berbesar hati, dan cara \\
& berpikir percaya hal ghaib, kebiasan hidup bertaqwa, pesta adat, pesta rasa \\
& syukur, proses mandudus, hidup berpindah-pindah, mangasa, mudik, \\
& upacara ritual, proses periapan pernikahan, mendirikan pondok, sikap selalu \\
& bersyukur kepada Tuhan Yang Maha Esa, sikap tenggang rasa, dan sikap \\
& pemberani. Sementara itu, pengembangan materi ajar dengan pendekatan \\
& sosiokultural layak untuk diterapkan pada proses belajar mengajar di kelas. \\
& Modul pengembangan materi ajar pendekataan sosiokultural, sudah melalui \\
& tes yang pertama. Mahasiswa dapat mengerjakaan beberapa pertanyaan dari \\
dosen dengan nilai rata-rata 84.
\end{tabular}

\begin{tabular}{|c|c|}
\hline Article Info & ABSTRACT \\
\hline $\begin{array}{l}\text { Article history: } \\
\text { Received: } \\
\text { 10 November } 2019 \\
\text { Revised: } \\
21 \text { December } 2019 \\
\text { Accepted: } \\
\text { 14 January } 2020 \\
\text { Keywords: } \\
\text { Folklore, sociocultural, } \\
\text { semiotic }\end{array}$ & $\begin{array}{l}\text { The purpose of this study is to describe the socio-cultural markers in Cerita } \\
\text { Rakyat Paser dan Berau books written by Syahidin, et al. and describe the } \\
\text { development of literary criticism teaching material through a sociocultural } \\
\text { approach. This research is a research development using the design of an } \\
\text { educational research and development (R\&D) research design. The results } \\
\text { of this study indicate that the markers contained in } 20 \text { Paser folklore and } 17 \\
\text { Berau folklore, namely the rational way of thinking, wise attitude, mutual } \\
\text { living habits, unyielding attitude, attitude of responsibility, attitude to help, } \\
\text { hunting habits, thinking superstition, mutual respect, thoughtful attitude, } \\
\text { irrational way of thinking, manly attitude, respect, mutual affection, } \\
\text { deliberation, steadfastness and heartfelt attitude, and unbelievable way of } \\
\text { thinking, habits of devout life, customary party, feast party gratitude, the } \\
\text { mandudus process, sedentary life, mangasa, homecoming, ritual } \\
\text { ceremonies, marriage preparation process, erecting a hut, always grateful }\end{array}$ \\
\hline
\end{tabular}


attitude to God, compassion, and courageous attitude. Meanwhile, the development of teaching materials with a sociocultural approach is feasible to be applied to the teaching and learning process in the classroom. The module for developing sociocultural teaching materials, has passed the first test for students to work on the questions that have been submitted by the lecturer with several questions and the students get an average score of 84 .

\section{PENDAHULUAN}

Negara Indonesia terdiri dari ribuan pulau yang memiliki kekayaan foklor. Salah satu kekayaan foklor tersebut adalah cerita rakyat yang memuat pesan-pesan moral. Cerita rakyat adalah cerita yang berasal dari masyarakat dan berkembang secara turun menurun di masyarakat. Buku yang diterbitkan oleh Kementerian Pendidikan Pengembangan dan Pembinaan Bahasa adalah salah satu buku yang memuat cerita rakyat, khususnya cerita rakyat Paser dan Berau.

Cerita rakyat atau dongeng biasanya diceritakan oleh orang tua kepada anak-anaknya sebagai pengantar tidur. Dalam cerita rakyat, pesan moral yang terkandung di dalamnya memuat berbagai macam nilai khususnya nilai sosial. Nilai sosial tersebut tertanam oleh masyarakat dalam berbagai budaya yang melingkupinya. Nilai sosial dalam setiap budaya tersebut dinamakan dengan sosiokultural.

Sosiokultural merupakan gambaran kehidupan masyarakat disuatu tempat tertentu terkait dengan kebisaan hidup, cara berpikir, dan sikap (Kasmi, 2015:76). Sosikultural adalah sebuah tempat kehidupan sosial dan perorangan dalam konteks tingkah laku afektif dan kongnitif. Seseorang dalam kehidupannya lebih kepada merasakan kenyataan dalam konteks sosial budaya sendiri. Dengan demikian, sosiokultural sangat jelas mendiami perilaku dalam sebuah entitas atau kelompok tertentu.

Seiring dengan kemajuan teknologi sekarang ini, manusia mengalami penurunan dalam nilai-nilai sosial di mana terdapat kemunduran intensitas kedekatan dalam ikatan sosial antara keluarga, kerabat, dan masyarakat. Kemunduran tersebut tidak sejalan dengan nilai-nilai sosial yang ada pada zaman dulu, di mana kebersamaan, kerukunan, dan ketulusan hati masih kuat.

Penurunan nilai-nilai sosial tersebut terjadi pula pada mahasiswa. Mahasiswa-mahasiswa yang kesehariannya adalah bertemu dengan teman, dosen, dan sebagainya ini memiliki penurunan dalam nilai sosial. Salah satunya adalah etika berbicara dengan dosen dan teman-temannya. Etika berbicara ini ditunjukkan dengan gaya berbicara yang santai ketika bersama dosen dan teman-temannya. Atas dasar itulah maka diperlukan pengembangan materi ajar dalam Mata Kuliah Kritik Sastra untuk menanamkan nilai-nilai sosial kepada mahasiswa.

Kritik sastra merupakan mata kuliah Program Studi Pendidikan Bahasa dan sastra Indonesia yang merupakan bidang studi sastra 
mengenai pertimbangan karya, yang membahas bernilai tidaknya sebuah karya sastra (Hermoyo, 2015:45). Dalam pembelajaran, mahasiswa masih kesulitan dalam proses mengkritik karya sastra. Adanya konsep pemikiran yang masih meluas dan belum dibatasi menjadi faktor utama dalam mengkritik suatu karya sastra. Hal tersebut tampak ketika mahasiswa melakukan praktik. Mahasiswa masih kesulitan dalam memberikan penilaian baik buruknya suatu karya sastra. Berdasarkan pemahaman bahwa suatu penilaian terhadap karya sastra sangat bermanfaat, maka perlu adanya pengembangan materi ajar mata kuliah Kritik Sastra melalui pendekatan sosiokultural.

Penelitian sebelumnya pernah dilakukan oleh Fanda Yunita Wutoy \& Yosefina Baru yang berjudul "Pengajaran Apresiasi Nilai-Nilai Cerita Rakyat Empat Mata dalam Pembelajaran Bahasa Indonesia sebagai Model Pembelajaran Kontekstual di Kabupaten Raja Ampat". Penelitian ini mengidentifikasi nilai-nilai yang dapat digunakan sebagai bahan pengajaran, yaitu nilai pendidikan religius, moral, sosial, dan budaya.

Berdasarkan penjelasan dan penelitian sebelumnya, maka penelitian yang berjudul Kajian Penanda Sosiokutural pada Buku Cerita Rakyat Paser dan Berau Karya Syahidin dkk untuk Pengembangan Materi Ajar Kritik Sastra ini layak untuk dilakukan. Hal tersebut didasarkan bahwa pendekatan sosiokultural yang ditemukan dalam suatu karya sastra yang meliputi kebiasaan hidup, cara berpikir, dan sikap dapat diterapkan oleh mahasiswa dalam kehidupan sehari-hari. Selain itu, memudahkan mereka dalam menilai baik buruknya suatu karya sastra melalui batasan konsep pada materi pendekatan sosiokultural.

\section{METODE}

Penelitian ini menggunakan desain penelitian educational research and development (R\&D). Menurut Sugiyono (Hanafi, 2017:139-141) desain penelitian $R \& D$ adalah potensi masalah, mengumpulkan informasi, desain produk, validasi desain, perbaikan desain, uji coba produk, revisi produk, uji coba pemakaian, dan revisi produk, pembuatan produk masal. Hasil produk penelitian ini adalah modul mata kuliah kritik sastra yang memuat materi pendekatan sosiokultural. Penelitian ini memiliki prosedur sebagai berikut. (1) Potensi masalah, meliputi (a) observasi, (b) analisis teoritis dan praktis terkait materi ajar mata kuliah kritik sastra, (c) penelusuran dokumen dari penelitian terdahulu, (2) Pengumpulan informasi dan data, meliputi (a) mencari sumber pustaka dan hasil penelitian yang relevan, (b) analisis kebutuhan pengembangan materi ajar kritik sastra kepada mahasiswa, (3). Desain produk, meliputi (a) penyusunan teks, format, dan bentuk modul sesuai dengan analisis kebutuhan dan (b) penyusunan rancangan kegiatan pembelajaran, (4). Uji validasi produk oleh validator untuk menilai dan memberi saran dan kritik, (5) Revisi produk, meliputi (a) penyempurnaan produk akhir dan (b) penyempurnaan dari revisi hasil uji coba sebelumnya, (5) Uji coba terbatas untuk menguji keefektifan produk materi ajar mata kuliah kritik sastra. Hasil pengembangan produk berupa modul mata kuliah kritik sastra yang memuat pendekatan sosiokultural.

Data penelitian ini berupa hasil wawancara dan angket terhadap 
mahasiswa Fakultas Keguruan dan Ilmu Pendidikan Bahasa dan Sastra Indonesia Universitas Balikpapan semester 5 yang berjumlah 10 mahasiswa. Data selanjutnya adalah dokumentasi penerapan pembelajaran mata kuliah kritik sastra yang memuat pengembangan materi pendekatan sosiokultural. Selain itu, data dalam penelitian ini adalah hasil validasi yang diperoleh dari dosen ahli materi. Sementara itu, data penelitian adalah buku Cerita Rakyat Paser dan Berau karya Syahidin, dkk.

Sumber data penelitian ini adalah mahasiswa Fakultas Keguruan dan Ilmu Pendidikan Bahasa dan Sastra Indonesia semester 5 yang berjumlah 10 mahasiswa. Selain itu, sumber data penelitian ini adalah dosen ahli materi untuk melakukan validasi terhadap pengembangan modul mata kuliah kritik sastra yang memuat materi pendekatan sosiokultural. Sumber data lainnya adalah buku Cerita Rakyat Paser dan Berau karya Syahidin, dkk.

Penelitian ini akan mengembangkan materi ajar mata kuliah kritik sastra melalui pendekatan sosiokultural. Dengan demikian, penelitian ini menggunakan pedoman wawancara, instrument tes, angket kebutuhan (kuesioner), dan lembar uji validasi. Teknik wawancara yang dipilih adalah wawancara terstruktur dengan memberikan pertanyaan kepada mahasiswa semester 5 terhadap penerapan materi pendekatan sosiokultural sebagai pengembangan materi ajar kritik sastra. Selanjutnya, teknik angket dalam penelitian ini digunakan untuk melihat respon mahasiswa semester 5 terhadap penerapan materi pendekatan sosiokultural sebagai pengembangan materi ajar kritik sastra. Instrument tes digunakan untuk melihat pemahaman mahasiswa dalam melakukan kegiatan kritik sastra melalui materi pendekatan sosiokultural sebagai pengembangan materi ajar kritik sastra. Lembar uji validasi yang ditujukan kepada dosen ahli materi untuk memperoleh hasil uji validasi materi ajar pendekaatan sosiokultural dalam mata kuliah kritik sastra untuk mengetahui kelemahan materi ajar yang dikembangkan.

Penelitian ini menggunakan teknik pengumpulan data yang digunakan untuk memperoleh data pertama dalam pengembangan materi ajar kritik sastra melalui pendekatan sosiokultural. Teknik pengumpulan data tersebut yaitu teknik wawancara, teknik tes pemahaman mahasiswa, dan teknik angket kebutuhan. Teknik yang digunakan untuk memperoleh data pertama adalah teknik wawancara untuk melihat tanggapan mahasiswa semester 5 terhadap pengembangan materi ajar melalui pendekatan sosiokultural. Teknik yang digunakan untuk memperoleh data kedua adalah tes pemahaman dan angket kebutuhan untuk merumuskan subtansi materi ajar kritik sastra melalui pendekatan sosiokultural. Teknik yang digunakan untuk data ketiga tentang hasil uji validasi adalah teknik angket lembar uji validasi yang diperoleh dari dosen ahli materi. Selain itu, untuk mendokumentasikan penelitian ini maka dilakukan teknik dokumentasi.

Teknik analisis data dilakukan dua tahap, tahap pertama adalah data kelayakan produk yang dihasilkan ditentukan melalui analisis hasil vaidasi ahli materi, tes, angket, dan lembar uji validasi ahli materi pembelajaran mata kuliah kritik sastra dengan pengembangan materi ajar pendekatan sosikultural kepada mahasiswa Fakultas Keguruan dan Ilmu Pendidikan Bahasa dan Sastra 
Indonesia Universitas Balikpapan semester 5. Data-data tersebut dianalisis secara deskriptif. Langkahlangkah analisis data tersebut adalah mengubah penilaian dalam bentuk kualitatif menjadi kuantitatif, menghitung skor rata-rata dari data yang telah terkumpul, dan mengubah skor rata-rata menjadi nilai kualitatif dengan memberikan kriteria (A,B,C,D,E).

Tahap kedua, data hasil uji coba berupa hasil wawancara oleh mahasiswa Fakultas Keguruan dan Ilmu Pendidikan Universitas Balikpapan semester 5, akan dianalisis secara kualitatif. Aktivitas dalam analisis data tersebut, yaitu reduksi data (data reduction), penyajian data (data display), dan kesimpulan (verification).

\section{HASIL DAN PEMBAHASAN}

1. Penanda Sosiokultural dalam Cerita Rakyat Paser

a. Penanda Sosiokultural dalam Cerita Rakyat Paser "Putri Petung"

1) Cara Berpikir Rasional Tokoh dalam Cerita Rakyat "Putri Petung"

Dikisahkan pada waktu itu Saipo, istri Datun, sedang hamil besar. Datun sangat sayang pada istrinya.

"Saipo, janganlah engkau banyak bekerja. Jagalah kandunganmu! Jangan sampai kandunganmu terganggu."

"Kak Datun, hal ini sengaja aku lakukan karena kurang baik jika orang hamil hanya berpangku tangan dan kurang gerak."

"Mengapa jadi begitu, Dik?"

"Bila semasa hamil kurang bergerak nanti akan sulit saat melahirkan karena bisa mengakibatkan kurang tenaga."
"Akan tetapi, janganlah Adik mengerjakan hal-hal yang terlalu berat."

"Sudahlah Kak. Jangan terlalu Kakak pikirkan. Ini sudah menjadi kebiasaanku."

Kebetulan pada saat itu padi sedang menguning. Tidak berapa lama lagi akan tiba masa panen. Bila tidak segera dipotong dikhawatirkan batang padi akan patah karena tidak mampu menahan berat isinya. Itulah yang sedang dilakukan Saipao, yakni menyiapkan peralatan untuk memanen padi. Ia membuat tikar dan lanjung serta alat untuk memotong padi (aniani). Terkadang Saipao merasakan sakit pada perutnya. Namun, hal itu tidak ia beritahukan kepada suaminya.

\section{Konteks}

Dikisahkan seorang istri datun yang bernama Saipo yang sedang hamil tua. Dia termasuk wanita yang kuat dan pekerja keras. di mana kehamilan yang sudah tua, Saipo tetap membantu suami di sawah untuk memanen padi.

Sang suami mengakhawatirkan Saipo yang mengerjakan pekerjaan memanen padi karena pekerjaan tersebut termasuk berat untuk orang hamil. Tetapi Saipo merasa tidak bisa diam berpangku tangan karena dia berpikiran orang hamil apabila kurang gerak akan sulit melahirkan.

\section{Makna Denotasi}

Pada dialog antara Datun dan Saipo tersebut terlihat bahwa Saipo sedang bekerja dalam kondisi hamil besar. Saipo sedang bekerja menyiapkan peralatan untuk memanen padi karena padi sudah menguning dan sudah 
waktunya dipanen. Datun yang melihat Saipo tersebut bermaksud menasehati Saipo agar tidak banyak bekerja karena dapat mengganggu kehamilanya. Saipo yang dinasehati seperti itu memberikan pemahaman kepada Datun bahwa pada saat keadaan hamil harus banyak bergerak agar proses melahirkannya lancar.

\section{Makna Konotasi}

Dalam potongan dialog antara Datun dan Saipo tersebut tampak bahwa Datun sedang menasehati Saipo yang sedang bekerja dalam keadaan hamil besar. Konotasi yang hendak disampaikan pada dialog tersebut adalah cara berpikir Datun tentang larangan untuk bekerja berat bagi wanita yang sedang hamil besar. Hal tersebut tampak pada pernyataan Datun kepada Saipo yang sedang melakukan pekerjaan menyiapkan peralatan untuk memanen padi. Saipo membuat tikar dan lanjung serta alat untuk memotong padi (ani-ani). Saipo tidak menghiraukan nasehat dari Datun. Menurut Saipo, harus banyak bekerja agar proses kelahirannya lancar.

\section{Mitos}

Dalam tinjauan medis, ada beberapa hal yang dapat meningkatkan resiko keselamatan ibu hamil, yaitu kurangnya kesadaran untuk melakukan pemeriksaan kesehatan selama hamil (antenatal care), ketidaktahuan ibu hamil maupun orang-orang terdekat tentang gejala yang menunjukkan adanya bahaya, serta adanya faktor kurang gizi yang dapat menyebabkan anemia (Astuti, Santosa, \& Utami, 2000:85). Selama masa kehamilan, wanita hamil boleh melakukan pekerjaan ringan dan menghindari pekerjaan yang banyak menguras tenaga. Atas dasar tersebut, wanita hamil yang sering bekerja diwajibkan untuk rutin memeriksakan kandungannya ke dokter untuk menghindari bahaya terhadap janin. Wanita hamil harus banyak istirahat demi menjaga kandungannya.

Penanda (siginifier) yang terdapat dalam percakapan antara tokoh Saipo dan Datun tersebut adalah adanya percakapan antara Saipo dan Datun yang dilatarbelakangi karena tokoh Saipo memaksakan dirinya untuk melakukan pekerjaan yang berat dalam keadaan hamil. Sementara itu, petanda (siginified) yang ditunjukkan adalah adanya pernyataan larangan oleh tokoh Datun kepada tokoh Saipo untuk tidak melakukan pekerjaan berat. Berdasarkan petanda dan penanda tersebut, maka makna denotatif dari percakapan tersebut adalah larangan tokoh Datun kepada tokoh Saipo untuk melakukan pekerjaan yang berat, sedangkan makna konotatifnya adalah cara berpikir rasional tokoh Datun kepada tokoh Saipo untuk tidak melakukan pekerjaan yang berat karena berbahaya bagi kehamilan. Dengan demikian, mitos yang diperoleh melalui makna denotatif dan konotatif tersebut adalah wanita hamil diperbolehkan untuk bekerja, tetapi bukan pekerjaan berat dan harus memiliki kesadaran untuk memeriksakan kehamilannya. Cara berpikir rasional merupakan bagian dari cara berpikir sosiokultural yang dimiliki oleh Masyarakat Paser. Dalam kehidupan sosial, Masyarakat Paser menanamkan sikap untuk saling menasehati karena rasa kepedulian yang tinggi antara manusia yang satu dengan manusia yang lain.

\section{2) Sikap Pantang Menyerah Tokoh dalam Cerita Rakyat "Lalung dan Putri Junjung Bulau"}


Tahukah kamu Nak! Sudah banyak pangeran dan raja muda meminangnya. Akan tetapi, tidak seorang pun yang dapat menjadikannya istri. Aku sendiri tidak mengetahui apa yang menyebabkan jadi begitu?"

Lalung termenung mendengar cerita Kakek Tua itu. Dia ingin mengetahui mengapa para pangeran dan raja-raja muda tidak dapat mempersunting putri itu untuk dijadikan permaisuri. Lalung bergumam, "Apakah aku bisa mendapatkannya. Aku merasa tidak mungkin mendapatkan gadis pujaan hatiku itu."

"Kenapa kamu termenung, Nak?" kakek tua bertanya sesudah mereka berdua terdiam beberapa saat.

"Tidak, Pak! Saya berpikir apakah mungkin saya dapat melamarnya. Jika menurut keterangan Bapak tadi, harapan saya sangat tipis untuk mendapatkannya," Lalung menjawab pertanyaaan kakek tua itu.

"Kenapa kamu berputus asa sebelum mencoba terlebih dahulu. Kita harus mencoba terlebih dahulu baru mengambil keputusan."

"Betul juga kata Bapak. Baiklah, Pak! Saya akan mencobanya."

\section{Konteks}

Lalung seorang pemuda biasa mendengarkan cerita dari sang kakek tentang seorang putri yang cantik. Sehingga banyak pangeran dan raja muda untuk mempersunting tetapi tidak satu pun yang dapat memperistri putri tersebut. Lalung pun terdiam dan berfikir apakah saya bisa mempersitri putrid tersebut karena pangeran dan raja muda tidak dapat mempersunting putri tersebut. Lalung juga ingin mengetahui kenapa para pangeran dan raja muda gagal memperistri putri. Sang kakek bertanya kenapa Lalung melamun, Lalung pun menjelaskan bahwa apakah dia bisa melamar putri tersebut. Kakek pun memberikan motivasi jangan putus asa sebelum mencoba. Lalung berpikir lagi untuk mencoba dan berusaha mendekati dan melamar sang putri.

\section{Makna Denotasi}

Pada narasi dan dialog tersebut tampak bahwa terdapat percakapan antara seorang kakek tua dengan Lalung. percakapan tersebut muncul karena Lalung sedang mengagumi kecantikan Putri Junjung Bulau. Lalung melihat putri tersebut sering mandi pagi dan sore ditemani oleh beberapa wanita cantik paruh baya. Rasa penasaran Lalung memuncak dan akhirnya ia bertanya kepada kakek tua tersebut. Kakek tua tersebut mengatakan bahwa putri tersebut sangat susah didapatkan karena terbukti banyak pangeran dan raja-raja muda tidak dapat mempersunting putri tersebut. Lalung yang mendengar hal tersebut merasa putus asa karena ia juga tidak mungkin bisa mendapatkan putri tersebut. Kakek tua yang mendengar hal tersebut segera memberikan semangat kepada Lalung untuk jangan berputus asa karena Lalung belum mencobanya. Mendengar nasehat dari kakek tua tersebut, akhirnya Lalung sadar dan berniat untuk mencoba mendapatkan putri tersebut.

\section{Makna Konotasi}

Konotasi yang digambarkan pada narasi dan dialog tersebut adalah sikap bekerja keras. Sikap ini dinyatakan oleh kakek tua kepada Lalung yang sedang berputus asa. Lalung merasa putus asa 
karena ia tidak mungkin mendapatkan Purri Junjung Bulau karena banyak pangeran dan raja-raja muda tidak dapat mempersunting putri tersebut. Kakek tua memberikan semangat kepada Lalung untuk mencoba mendapatkan putri tersebut. Secara langsung, tanda yang ingin disampaikan kakek tua kepada Lalung adalah sikap pantang menyerah dalam kehidupan. Kakek tua tersebut mengajarkan kepada Lalung untuk terus berusaha dan jangan menyerah sebelum mendapatkan apa yang diinginkan.

\section{Mitos}

Masyarakat Paser telah mengenal sikap bekerja keras sejak dahulu kala dan diturunkan secara turun temurun. Sikap bekerja keras diberikan oleh orang-orang tua kepada seseorang yang masih muda agar selalu berusaha dan jangan berputus asa dalam bentuk dukungan sosial. Dukungan sosial ini digunakan untuk memberi motivasi kepada orang lain dalam membentuk kepribadian yang positif. Sikap bekerja keras merupakan salah satu pendidikan karakter yang digunakan sebagai pegangan hidup. Sikap bekerja keras adalah sifat seseorang yang tidak mudah berputus asa dengan disertai oleh kemauan yang keras untuk berusaha mencapai tujuan dan citacitanya (Elfindri dalam Sulastri \& Alimin, 2017:158). Dengan demikian, sikap bekerja keras yang dinyatakan oleh kakek tua kepada Lalung adalah bentuk motivasi yang digunakan sebagai pegangan Lalung agar bekerja keras untuk mendapatkan apa yang diinginkan dan dicita-citakan dalam kehidupan.

Penanda (siginifier) yang terdapat dalam percakapan antara tokoh Lalung dan Kakek Tua tersebut adalah adanya percakapan antara tokoh Lalung dan Kakek Tua yang dilatarbelakangi karena tokoh Lalung sangat menyukai wanita yang merupakan gadis pujaan hatinya. Sementara itu, petanda (siginified) yang ditunjukkan adalah adanya pernyataan oleh tokoh Kakek Tua kepada tokoh Lalung yang berupa nasihat untuk tidak berputus asa. Berdasarkan petanda dan penanda tersebut, maka makna denotatif dari percakapan tersebut adalah pernyataan tokoh Kakek Tua kepada tokoh Datun untuk tidak berputus asa, sedangkan makna konotatifnya adalah sikap pantang menyerah yang diajarkan oleh tokoh Kakek Tua kepada tokoh Lalung. Dengan demikian, mitos yang diperoleh melalui makna denotatif dan konotatif tersebut adalah adanya sikap yang ditanamkan oleh masyarakat Paser yang diturunkan secara turuntemurun untuk memiliki sikap pantang menyerah dalam kehidupan. Sikap pantang menyerah merupakan sikap sosiokulural yang dimiliki oleh masyarakat Paser yang diturunkan secara turun-menurun sebagai pegangan dalam menjalani kehidupan.

\section{3) Cara Berpikir Percaya terhadap Hal Ghaib}

"Setelah mengalahkan para prajurit di pos pertahanan, para pemberontak segera menaiki istana kerajaan. Raja Mas Anom yang melihat para pemberontak sudah mulai mendekati istana kerajaan dengan serta merta bersiap menghunuskan pedangnya. Dia pun kemudian menyambar-nyambarkan pedang dan mengeluarkan jurus maut. Namun, serangan pemberontak yang bertubi-tubi dari segala penjuru membuat pertahanan Raja Mas Anom melemah. Para pemberontak pun tidak memberi 
kesempatan Raja Mas Amom untuk melakukan perlawanan. Akhirnya, Raja Mas Anom terbunuh. Dan, hal aneh pun terlihat. Meskipun tubuhnya terhujam oleh serangan Mandau, parang, dan kelewang para pemberontak, namun tubuh Raja Mas Anom tidak terdapat bekas luka dan goresan. Sehingga, timbullah kepercayaan masyarakat pada waktu itu bahwa Raja Mas Anom tidak meninggal, tetapi menjadi Raja Uwok (bahasa Paser) atau Raja Hantu."

\section{Konteks}

Dikisahkan di masa peperangan seorang raja bernama Mas Anom berhasil mengalahkan para prajurit di pos pertahanan. Raja Mas Anom mengetahui pemberontak sudah mulai mendekati istana kerajaan. Maka Mas Anom mulai bergerak bersiap menghunuskan pedangnya dan mkenyambar-nyambarkan pedangnya dan mengeluarkan jurus maut. Namun serangan pembenrontak bertubi-tubi membuat pertahanan Mas Anom melemah. Akhirnya, Raja Mas Anom terbunuh tetapi anehnya tubuh Raja Mas Anom tidak ada bekas luka. Masyarakat mempercayai bahwa Raja Mas Anom tidak meninggal tetapi menjadi Raja Uwonk atau Raja Hantu.

\section{Makna Denotasi}

Pada narasi tersebut tampak bahwa telah terjadi peperangan antara Raja Mas Anom dengan pemberontak. Raja Mas Anom siap melakukan perlawanan terhadap pemberontak yang mulai mendekati istananya. Setelah pemberontak memasuki istana Raja Mas Anom, maka pertempuran terjadi. Raja Mas Anom diserang dari segala penjuru oleh pemberontak. Dan akhirnya, kekuatan Raja Mas Anom melemah. Raja Mas Anom terhunus Mandau, parang, dan kelewang dari pemberontak karena ia tidak memiliki kekuatan. Raja Mas Anom yang telah wafat tersebut tidak memiliki bekas luka. Oleh sebab itu, masyarakat yang melihat hal tersebut mempercayai bahwa Raja Mas Anom tidak meninggal, tetapi berubah menjadi Raja Uwok (bahasa Paser) atau Raja Hantu.

\section{Makna Konotasi}

Konotasi yang hendak disampaikan pada narasi tersebut adalah adanya kepercayaan terhadap hal-hal mistis. Hal tersebut muncul karena adanya kepercayaan masyarakat Paser tentang suatu ilmu yang dimiliki oleh Raja Mas Anom. Masyarakat mempercayai bahwa Raja Mas Anom memiliki kekuatan sakti. Masyarakat percaya kalau Raja Mas Anom masih hidup meskipun telah wafat. Kepercayaan tersebut muncul karena tidak ditemukannya bekas luka di tubuh Raja Mas Anom. Dalam narasi tersebut, kepercayaan masyarakat terhadap kekuatan sakti tersebut menandakan cara berpikir masyarakat Paser.

\section{Mitos}

Sebelum mengenal agama, masyarakat Paser percaya akan animisme supernatural, syamanisme, dan sebagainya. Masyarakat Paser saling terikat dengan makhluk-makhluk halus, kekuatan gaib, dan kekuatan sakti. Ilmu gaib merupakan suatu kepercayaan kuno bagi masyarakat Paser. Salah satu kepercayaan yang terdapat pada narasi tersebut adalah kepercayaan pada kekuatan sakti. Kekuatan sakti ini dimiliki oleh Raja Mas Anom karena ketika bertempur melawan pemberontak, Raja Mas Anom wafat dengan tidak memiliki bekas luka. Hal tersebut membuat 
masyarakat berpikir bahwa Raja Mas Anom akan menjadi Raja Uwok atau Raja Hantu.

Dalam Agama Islam, kematian atau maut adalah berpisahnya ruh dengan jasad. Pada saat pemisahan tersebut, ruh berada di dalam Alam Barzakh atau alam kubur. Manusia yang telah meninggal atau pindah ke alam lain, tidak akan kembali ke alam semula. Begitu juga dengan ruh yang telah pindah ke alam Barzakh juga tidak akan kembali ke alam dunia. Dengan demikian, kepercayaan masyarakat Paser yang menganggap bahwa Raja Mas Anom menjadi Raja Hantu karena memiliki kekuatan sakti adalah tidak mungkin. Hal tersebut karena ruh Raja Mas Anom telah berada di alam Barzakh. Jika, masyarakat masih melihat Raja Mas Anom setelah wafat, maka itu adalah Jin yang menyerupai Raja Mas Anom.

Penanda (siginifier) yang terdapat dalam narasi tersebut adalah penggambaran kematian tokoh Raja Mas Anom akibat perkelahiannya dengan pemberontak. Sementara itu, petanda (siginified) yang ditunjukkan adalah adanya pernyataan bahwa tokoh Raja Mas Anom tidak meninggal, tetapi menjadi Raja Uwok (Raja Hantu) karena tidak adanya bekas luka dari tokoh Raja Mas Anom akibat perkelahiannya dengan pemberontak. Berdasarkan petanda dan penanda tersebut, maka makna denotatif dari percakapan tersebut adalah kematian tokoh Raja Mas Anom akibat perkelahiannya dengan pemberontak. Sedangkan makna konotatifnya adalah cara berpikir percaya terhadap hal ghaib yang dilakukan oleh Masyarakat Paser dengan anggapan bahwa tidak adanya bekas luka di badan tokoh Raja Mas Anom menjadikannya sebagai Raja Uwok (Raja Hantu). Dengan demikian, mitos yang diperoleh melalui makna denotatif dan konotatif tersebut adalah kepercayaan Masyarakat Paser terhadap hal ghaib karena zaman dahulu, mereka belum memiliki agama. Padahal, menurut agama, orang yang telah meninggal telah berada di alam Barzakh dan tidak dapat berubah bentuk. Cara berpikir Masyarakat Paser tersebut adalah bagian dari sosiokultural karena mereka dulu mempercayai hal-hal ghaib sebagai bagian dari kehidupan.

\section{b. Penanda Sosiokultural dalam Cerita Rakyat Berau \\ 1) Kebiasaan Hidup Musyawarah Tokoh dalam Cerita Rakyat Kabupaten Berau "Aji Surya Natakesuma"}

Sebagai seorang yang bijaksana, Rangga Batara tidak dapat memihak kepada putrinya. Walaupun dia sangat sayang kepada putri tunggalnya. Dengan hati yang sangat berat, beliau melaksanakan musyawarah. Hasil musyawarah kerajaan memutuskan menghukum Kannik dengan cara menghanyutkannya pada sebuah rakit di Laut Selatan Makasar. Keputusan itu harus dilaksanakan dengan segera.

\section{Konteks}

Ada kisah seorang raja yang bernama Aji Surya Natakesuma memiliki anak yang bernama Kannik. Anaknya sedang difitnah oleh seseorang yang tidak menyukai putrinya. Masyarakat mempercayai kalau Kannik melakukan perbuatan tersebut. Raja Aji Surya Natakesuma pun tidak bisa membela anaknya. Dengan hati yang berat beliau melakukan musyawarah untuk memutuskan menghukun Kannik yang 
disayanginya dengan cara menghanyutkan pada sebuah rakit di Laut Selatan Makasar.

\section{Makna Denotasi}

Makna denotasi pada narasi di atas adalah Rangga Batara tidak dapat memihak kepada putrinya dengan hati yang sangat berat, beliau melaksanakan musyawarah. Hasil musyawarah kerajaan memutuskan menghukum Kannik dengan cara menghanyutkannya pada sebuah rakit di Laut Selatan Makasar.

\section{Makna Konotasi}

Makna konotasi dapat dilihat pada kebiasaan di kerajaan yang dipimpin oleh Rangga Batara bersama rakyatnya merundingkan masalah yang dialami oleh anak semata wayangnya yaitu, Kannik untuk memutuskan hukuman apa yang harus ditetapka oleh Kannik. Hal tersebut nampak pada kutipan sebagai berikut, Dengan hati yang sangat berat, beliau melaksanakan musyawarah. Hasil musyawarah kerajaan memutuskan menghukum Kannik dengan cara menghanyutkannya pada sebuah rakit di Laut Selatan Makasar.

\section{Mitos}

Kebiasan musyawarah yang dilakukan oleh masyarakat Banua yang dimpimpin oleh Rangga Batara untuk memutuskan suatu masalah merupakan suatu keputusan yang tepat. Untuk menghasilkan keputusan yang disepakati oleh orang banyak.

Dalam kehidupan bersama, mutlak perlu menegakkan musyawarah dalam menghadapi dan memecahkan masalah-masalah bersama. Makin besar suatu kelompok semakin besar pula ditegak musyawarah. Musyawarah meruapakan sendi kehidupan masyarakat yang digunakan sebagai prinsip dan termasuk syariat (Hanafi, Muhammad, 2013).

Penanda (siginifier) yang terdapat dalam narasi tersebut adalah penceritaan tokoh Rangga Batara yang ingin melakukan sikap adil meskipun harus mengorbankan keluarga. Sementara itu, petanda (siginified) yang ditunjukkan adalah adanya keputusan yang dinyatakan oleh tokoh Rangga Batari demi keadilan. Berdasarkan petanda dan penanda tersebut, maka makna denotatif dari percakapan tersebut adalah sikap adil yang dilakukan oleh Rangga Batari untuk menghukum tokoh Kannik meskipun mengorbankan keluarga. Sedangkan makna konotatifnya adalah pernyataan tokoh Rangga Batari untuk menghukum Kannik yang dilakukan dengan cara musyawarah. Dengan demikian, mitos yang diperoleh melalui makna denotatif dan konotatif tersebut adalah kebiasaan musyawarah yang dilakukan secara turun-temurun oleh Mayarakat Berau untuk menghasilkan keputusan yang tepat. Kebiasaan musyawarah yang dilakukan oleh Masyarakat Paser adalah kebiasaan hidup sosiokultural karena melibatkan orang lain untuk memcahkan masalah dan mengambil keputusan bersama.

\section{2) Kebiasaan Hidup Gotong Royong dalam Cerota Rakyat "Gua Sarang Burung Pallas Baruni"}

Pada zaman dahulu, masyarakat di daerah Berau hidup tentram, damai, dan sejahtera lahir batin. Hidup dan kehidupan berlangsung dengan penuh kebersamaan dan dengan semangat gotong royong yang tinggi, baik dalam melaksanakan kepentingan pribadi maupun melaksanakan kepentingan bersama. 


\section{Konteks}

Pada zaman dahulu masyaerakat daerah Berau memiliki kebisaan hidup selalu bergotong royong yang tinggi. Kebiasaan gotong royong tersebut dilakukakan untuk kepntinggan pribadi ataupun kepentingan Bersama. Menurut masyarakat Berau kebisaan hidup gotong royong berdampak hidup menjadi lebih tenang dan tenteram.

\section{Makna Denotasi}

Makna denotasi pada kutipan di atas mendeskrpsikan bahwa pada zaman dahulu masyarkat Berau hidup tentram, damai, dan sejahtera lahir batin. Masyarakat Berau dalam kehidupan sehari-hari berlangsung dengan penuh kebersamaan dan semangat gotong royong sangat tinggi. Di mana masyarakat Berau lebih mengutamakan kepentingan bersama daripada kepentingan diri sendiri.

\section{Makna Konotasi}

"Masyarakat di daerah Berau hidup tentram, damai, dan sejahtera lahir batin. Hidup dan kehidupan berlangsung dengan penuh kebersamaan dan dengan semangat gotong royong yang tinggi".

Kutipan di atas dikonotasikan bahwa kebiasaan hidup bergotong royong masyarakat Berau dalam mengerjakaan ssuatu selalu dilakukan secara bersama-sama. Dengan adanya kebiasaan hidup bergotong royong maka masyarakt Berau hidup dalam kecukupan hasil sawah dan landang selalu berlebihan setiap tahun. Masyarakat Berau juga memiliki kebiasaan yang kental dengan saling tolong menolong dan bantu membantu antar sesama. Kebiasaan tersebut sudah menjadi kewajiban masyarakat Berau yang harus dilaksanakan untuk mewujudkan hidup yang tentram di masyarakat.

Mitos

Masyarakat Berau mempercayai untuk hidup tentram salah satunya adalah memiliki kebiasaan hidup gotong-royong dalam melaksankan kepentingan Bersama. Kebiasaan hidup gotong royong harus diterapkan disetiap elemen atau lapisan masyarakat Indonesia. Supaya semua pekerjaan yang berat mennjadi ringan. Selain itu juga gotong royong menumbuhkan hubungan kekerabatan dan silaturohim semakin erat. Menurut Effendi (2013) gotong royong merupakan budaya yang telah tumbuh dan berkembang dalam kehidupan sosial masyarakat Indonesia sebagai warisan yang telah eksis secara turun temurun.

Penanda (siginifier) yang terdapat dalam narasi tersebut adalah penggambaran kebiasaan hidup Masyarakat Berau. Sementara itu, petanda (siginified) yang ditunjukkan adalah adanya kebiasaan hidup gotong royong yang digambarkan dalam Masyarakat Berau. Berdasarkan petanda dan penanda tersebut, maka makna denotatif dari percakapan tersebut adalah penggambaran kebiasaan hidup Masyarakat Berau, sedangkan makna konotatifnya adalah kebiasaan hidup Masyarakat Berau dalam melakukan kepentingan pribadi atau bersama. Dengan demikian, mitos yang diperoleh melalui makna denotatif dan konotatif tersebut adalah kebiasaan hidup gotong royong yang dilakukan oleh Masyarakat Berau mengakibatkan mereka dapat hidup tenteram. Kebiasaan hidup ini adalah bagian dari kebiasaan hidup sosiokultural karena melibatkan orang lain untuk membantu adalah suatu bentuk kepedulian sosial. 


\section{3) Cara Berpikir yang Tidak Logis Tokoh dalam Cerita Rakyat Kabupaten Berau "Kepala Lading"}

Panjang rantau itu tidak kurang dari $1 \mathrm{~km}$, memnjang dari hilir ke hulu, seperti kampung di dalam air. Namun, kaku laksana batu. Setelah melewati Lamin Talansur, barulah si ayah teringat akan anaknya. Ketika menoleh kebelakang, ternyata anaknya sudah tidak ada lagi. Hatinya pun bergetar ketakutan. Ia baru sadar bahwa telah terjadi sesuatu pada diri anaknya. Ia langsung teringat bahwa tadi si anak minta dibelikan buah manggis tetapi tidak dikabulkanya. Berarti si anak kapuunan. Dengan rasa takut dan ngeri si ayah memutar haluan perahunya dan menuju ke hilir.

\section{Konteks}

Cerita Rakyat Kepala Lading mengisahkan seorang ayah bersama anaknya pulang kampung dengan melewati sungai dengan menggunakan kapal. Setelah melewati Lamin Talansur sang ayah baru menyadari kalau anaknya sudah tidak ada di belakangnya. Ayahnya mulai panik mencari anaknya dan baru menyadari kalau tadi di perjalanan anaknya meminta untuk dibelikan buah manggis tetapi belum dibelikan. Ayahnya pun berpikiran kalau anaknya kepunnan karena tidak dibelikan buah manggis.

\section{Makna Denotasi}

Makna denotasi pada narasi di atas adalah menjelaskan bahwa ada seorang ayah dan anaknya sedang melewati sungai. Tetapi setelah melewati Lamin kaku laksana batu, barulah dia teringat anaknya dan menoleh kebelakang ternyata anak tidak ada. Hatinya pun bergetar ketakutan. Ia baru sadar bahwa anaknya tadi meminta dibelikan buah manggis tetapi tidak dikabulkan. Maka anak tersebut kapunaan, dengan rasa takut. Ia memutar perahunya menuju kehilir untuk mencari anaknya

\section{Makna Konotasi}

Berarti si anak kapuunan. Dengan rasa takut dan ngeri si ayah memutar haluan perahunya dan menuju ke hilir. Pola berfikir, kaku laksana batu yang mempercayai mitos dikonotasikan bahwa seseorang yang menginginkan sesuatu tetapi tidak terwujud atau tidak sempat memakan makanan sudah ditawarkan maka di dalam perjalannnya akan mendapat celaka atau musibah.

\section{Mitos}

Masyarakat Kalimantan Timur mempercayai apabila seseorang mengiginkan sesuatu tidak terwujud, ditawari makanan dan minuman terutama makanan singkong, ketan, tape, dan minuman kopi tidak terwujud ataupun tidak dilaksanakan. Maka orang tersebut akan mengalami musibah. Mitos tentang kepuhunan masih dipercayai sampai sekarang dikalangan masyarakat Borneo. Salah satunya adalah masyarakat Berau.

Penanda (siginifier) yang terdapat dalam narasi tersebut adalah penceritaan tokoh Ayah yang menyaksikan bahwa anaknya telah meninggal. Sementara itu, petanda (siginified) yang ditunjukkan adalah adanya pernyaaan tokoh Ayah terhadap anaknya bahwa tokoh Anak meninggal karena kepuhunan. Berdasarkan petanda dan penanda tersebut, maka makna denotatif dari percakapan tersebut adalah kematian tokoh anak yang disebabkan tokoh Ayah tidak 
mengabulkan permintaannya, sedangkan makna konotatifnya adalah cara berpikir tidak logis tokoh Ayah yang menyatakan bahwa tokoh Anak meninggal karena permintaannya tidak dituruti. Dengan demikian, mitos yang diperoleh melalui makna denotatif dan konotatif tersebut adalah cara berpikir tidak logis Mayarakat Berau tentang kepuhunan. Cara berpikir ini termasuk dalam bagian cara berpikir sosiokultural karena cara berpikir ini telah dipercayai oleh Masyarakat Berau.

\section{Pengembangan Materi Ajar dalam} Mata Kuliah Kritik Sastra

a. Hasil Tes Pengembangan Materi Ajar Kritik Sastra melalui Pendekatan Sosiokultural

Kemampuan menelaah hasil karya sastra salah satunya adalah Cerita Rakyat Paser dan Berau pada mahasiswa Program Studi Pendidikan Bahasa dan Sastra Indonesia Universitas Balikpapan sebagaimana dapat menjawab pertanyaanpertanyaan sebagai berikut.

(1) Sebutkan dan jelaskan pendekatan sastra!

(2) Analisislah karya sastra Indonesia dengan menggunakan pendekataan sosiokultural. Selanjutnya, lakukan kegiataan mengkritik untuk mendapatkan makna dari karya sastra tersebut!

(3) Analisislah karya sastra Indonesia dengan menggunakan pendekataan sosiokultural melalui teori posmodernisme! Selanjutnya, lakukan kegiataan mengkritik untuk mendapatkan makna dari karya sastra tersebut!

(4) Sosiokultural yang Anda dapat selanjutnya Anda kaitkan dengan kehidupan yang ada di masyarakat.
Berdasarkan pertanyaan-pertanyaan tersebut dapat disimpulkan bahwa mahasiswa dapat mengkritisi sebuah karya sastra melalui pendekatan sosiokultural.

\section{b. Hasil Angket Pengembangan Materi Ajar Kritik Sastra melalui Sosiokultural \\ Pendekatan}

Berdasarkan hasil angket dapat disimpulkan bahwa mahasiswa semester 5 Fakultas Keguruan dan Ilmu Pendidikan Program Studi Pendidikan Bahasa dan Sastra Indonesia Universitas Balikpapan dapat menjawab semua pertanyaan dengan respon yang bervariatif. Pertanyaan 1 mahasiwa merasa tertarik dan tidak membosankan dengan menggunakan pendekataan sosiokultural pada mata kuliah Kritik Sastra dengan mendapatkan respon $80 \%$. Pada pertanyaan ke 2 dengan materi pendekataan sosiokultural, mahasiswa memiliki kemauan yang tinggi untuk memahami teks sastra mendapat respon $80 \%$. Pernyataan ke 3 mendapatkan respon $75 \%$ dengan pertanyaan adanya materi pendekataan sosikultural, mahasiwa memiliki kemamuan tinggi untuk membaca karya sastra. Pertanyaan ke 4 mendapatkan respon $82.5 \%$ menyatakaan pendekataan sosiokultural membuat mahasiswa berpikir kritis terhadap teks sastra. Pertanyaan ke 5 mendapatkan respon 87,5 di mana adanya materi pendekataan sosiokultural memudahkan mahasiswa memahami konsep kritik sastra. Pertanyaan ke 6 materi pendekataan sosiokultural memudahkan mahasiswa untuk mempelajari sesuatu yang berkaitan dengan kehidupan sehari-hari, mendapatkan respon $87,5 \%$. Pertanyaan ke 7 materi pendekataan 
sosiokultural memudahkan mahasiwa untuk memberi penilaian terhadap teks sastra, dengan mendapat respon $90 \%$. Pertanyaan ke 8 dan 12 mendapat respon $90 \%$ dengan pertanyaan materi pendekataan sosiokultural memudahkan mahasiswa untuk menemukan nilai-nilai dalam teks sastra yang berupa kebiasaan hisup, cara berpikir, dan bersikap. apertanyaan ke 9 mendapatkan respon $80 \%$ dengan pertanyaan bahwa materi pendekataan sosiokultural memudahkan mahasiswa dalam membuat batasaan konsep dalam kriik sastra. Pertanyaan ke 10 mendapatkan respon $80 \%$ dengan pertanyaan bahwa materi pendekataan sosiokultural perlu untuk diterapkan dalam perkuliahaan yang terkait dengan sastra. pernyataan ke 11 menyatakaan dengan materi pendekataan sosiokultural, mahasiwa dapat menambah wawasan tentang materi pendekataan sastra pada mata kuliah kritik sastra dengan mendapat respon $90 \%$.

\section{c. Hasil \\ Wawancara \\ Pengembangan Materi Ajar Kritik Sastra melalui Pendekatan Sosiokultural}

Berdasarkan hasil wawancara sepuluh mahasiswa mereka menyatakaa mengalami kesulitaan dalam menelaah dan menilai sebuah karya sastra karena keterbatasaan dalam membaca karya sastra dan kurangnya pemahaan tentang dasar penilaian karya sastra. Setelah dosen menggunakaan pendekatan sosiokultural, mahasiwa lebih mudah menelaah dan menilai karya sastra. Penyajian yang disampaikan oleh dosen dalam menyampaikan materi dengan mengunakan modul, bahasa yang komunikatif dan buku Cerita Rakyat Paser dan Berau merupakan daya tarik mahasiswa untuk mengikuti proses pembelajaraan pada mata kuliah kritik sastra. Selain itu, mahasiswa juga dapat menelaah dan menilai sebuah karya sastra adanya pendekataan sosiokultural. Mahasiwa merasa pembelajaran menggunakan pendekataan sosiokultural sangat menarik, lebih efektif dan efisien. Hal tersebut karena pendekataan sosiokultural berhubungan dengan sosial, budaya, dan masyarakat. Di mana tiga konsep tersebut tidak jauh dengan kehidupan sehari-hari, maka mahasiswa lebih mudah untuk memahami. Selain itu, mahasiwa termotivasi dalam menjalani proses belajar dengan adanya pengembangan materi ajar pendekatan sosikultural, karena mahasiswa inggin mengenal budaya-budaya yang ada di Indonesia salah satunya budaya Paser dan Berau.

\section{d. Hasil Validasi Ahli Materi Pengembangan Materi Ajar Kritik Sastra melalui Pendekatan Sosiokultural}

Berdasarkan hasil validasi dari aspek kualitas materi ajar dinyatakan sangat baik dengan mendapat nilai 75 dengan presentase 91,25\% dari aspek isi mendapatkan nilai 83 dengan presentase $92 \%$ dinyatakan sangat baik. Maka materi ajar dengan pendekatan sosikultural layak untuk diterapkan pada matakuliah kritik sastra. Adapun masukan atau komentar yang disampaikan oleh ahli materi untuk penyempurnaan modul adalah untuk kedalaman materi perlunya teori yang berkenaan dengan sosiokultural dari para pakar yang dapat mendukung teori yang sudah ada. Selain itu, untuk keaktualan materi, ahli materi meminta ditambahkan pembahasan zaman melenial yang berkaitan dengan sosiokultural. Ahli materi memberi 
masukan di dalam modul perlu ditambahkan contoh-contoh yang berhubungan dengan local wisdom atau kearifan lokal sebagai telaah sosiokultural yang ada di masyarakat sekitar. Adanya masukkan dari ahli materi sangat bermanfaat untuk penelitian ini supaya pengembangan materi dengan pendekataan sosiokultural lebih baik untuk digunakaan dalam kegiatan belajar mengajar pada mata kuliah kritik sastra.

\section{PENUTUP}

Berdasarkan hasil penelitian yang telah dilakukan, maka dapat diperoleh kesimpulan sebagai berikut.

Penanda yang terdapat pada dua puluh cerita dalam cerita rakyat Paser, yaitu cara berpikir rasional, sikap bijaksana, kebiasaan hidup gotong royong, sikap pantang menyerah, sikap tanggung jawab, sikap tolong menolong, kebiasaan hidup berburu, cara berpikir percaya takhayul, sikap saling menghargai, sikap bijaksana, cara berpikir tidak rasional, sikap gagah, sikap menghormati, sikap saling menyayangi, sikap musyawarah, sikap tabah dan berbesar hati, dan cara berpikir percaya hal ghaib. Sementara itu, penanda yang terdapat pada tujuh belas cerita dalam cerita rakyat Berau, yaitu kebiasan hidup bertaqwa, pesta adat, pesta rasa syukur, proses mandudus, musyawarah menggunakan nama dewa, hidup berpindah-pindah, mangasa (mengumpulkan makanan), mudik, upacara ritual, proses persiapan pernikahan, mendirikan pondok, sikap selalu bersyukur kepada Tuhan Yang Maha Esa, sikap gotong royong, sikap tenggang rasa, sikap suka menolong, dan sikap pemberani.

Berdasarkan penerapan modul pengembangan materi ajar dengan pendekatan sosiokultural pada mata kuliah Kritik Sastra, maka pengembangan materi ajar dengan pendekatan sosiokultural layak untuk diterapkan pada proses belajar mengajar di kelas. Modul pengembangan materi ajar pendekataan sosiokultural, sudah melalui tes yang pertama tes untuk mahaiswa dapat mengerjakaan soal yang sudah disampaikan oleh dosen dengan beberapa pertanyaa dan mendapatkan nilai rata-rata 84 . tes yang kedua dengan cara penyebaran angket kepada mahsiswa dengan mendapatkan respon setuju dan sangat setuju dengan ratarata 84,375 . tes yang ketiga dengan cara wawancara secara terbuka. adanya pengembangan materi ajar dengan pendekataan sosiokultural mendapatkan tanggapan yang baik. Mahasiwa setuju adanya pendekataan sosiokultural untuk dapat mengkritisi sebuah karya sastra. Tes yang ketiga dengan cara memberikan angket kepada para ahli materi untuk medapatkan masukan dan penilaian. Adapun hasil angket para ahli materi, hasil validasi dari aspek kualitas materi ajar dinyatakan san baik dengan mendapat nilai 75 dengan presentase 91,25\% dari aspek isi mendapatkan nilai 83 dengan presentase $92 \%$ dinyatakan sangat baik.

Berdasarkan simpulan, peneliti memberikan saran agar produk penelitian ini diharapkan dapat digunakan peneliti selanjutnya untuk pengembangan materi ajar dengan pendekataan sastra lain pada mata kuliah kritik sastra. Selain itu, diharapakan adanya pengembangan bahan ajar pada buku Cerita Rakyat Paser dan Berau pada mata kuliah kritik sastra maupun apresiasi sastra. 


\section{DAFTAR PUSTAKA}

Astuti, A.B., Santosa, S.W., \& Utami, M.S. (2000). Hubungan antara Dukungan Keluarga dengan Penyesuaian Diri Perempuan pada Kehamilan Pertama. Jurnal Psikologi, 27(2), 84-95. Diakses 31 Oktober 2019 Pukul 21.04 dari

https://jurnal.ugm.ac.id/jpsi/artic le/view/7001

Effendi, Noer Tadjuddin. (2013). Budaya Gotong Royong Masyarakat dalam Perubahaan Sosial Saat Ini. Jurnal Pemikiran Sosiologi. Volume 2. No 1. Diakses 9 November 2019 dari https://jurnal.ugm.ac.id/jps/articl e/view/23403/pdf

Hanafi Muhammmad. (2013). Kedudukan Musyawarah dan Demokrasi Di Indonesia. Jurnal Cita Hukum Vo. 1. No. 2. Desember 2013. Universitas Islam Negeri.

Hanafi. (2017). Konsep Penelitian R\&D dalam Bidang Pendidikan. Jurnal Kajian Keislaman, 4(2), 129-150. Diakses 22 Oktober 2019 Pukul 21.17 dari http://jurnal.uinbanten.ac.id/inde x.php/saintifikaislamica/article/ view/1204

Hermoyo, R.P. (2015). Analisis Kritik Sastra Puisi "Surat kepada Bunda: tentang Calon Menantunya" Karya W.S Rendra. Jurnal Didaktis. 1(15), 44-53. Diakses 15 Oktober 2019 Pukul $\quad 13.10 \quad$ dari http://journal.umsurabaya.ac.id/index.php/didakti s/article/view/40
Hoed. B.H. (2014). Semiotik dan Dinamika Sosial Budaya. Depok: Komunitas Bambu.

Kasmi, Hendra. (2015). Latar Sosiokultural Keacehan dalam Novel Teuntra Atom Karya Tayeb Loh Angen. Jurnal Metamorfosa, 2(3), 75-84. Diakses 2 September 2019 Pukul $20.25 \quad$ dari https://metamorfosa.stkipgetsem pena.ac.id/?journal=home\&page $=$ article $\&$ op $=$ view $\&$ path $\% 5 \mathrm{~B} \%$ $\underline{5 \mathrm{D}=37 / 0 \text { ? journal=home\&page }=}$ article\&op=view\&path\%5B $\% 5$ $\mathrm{D}=37 / 0$

Sulastri, Septiana \& Alimin, Al Ashadi. (2017). Nilai Pendidikan Karakter Kerja Keras dalam Novel 2 Karya Donny Dhorgantoro. Jurnal Pendidikan Bahasa, 6(2), 156-168. Diakses 15 Oktober 2019 Pukul 10 Oktober 2019 dari http://journal.ikippgriptk.ac.id/i ndex.php/bahasa/article/view/61 $\underline{9}$

Wutoy, Y.F., \& Baru, Yosefina. Pengajaran Apresiasi Nilai-Nilai Cerita Rakyat "Empat Mata" dalamPembelajaran Bahasa Indonesia sebagai Model PembelajaranKontekstual di Kabupaten Raja Ampat. Jurnal Triton Pendidikan, 1(1). Diakses 12 Desember 2019 Pukul 18.38 dari

https://www.neliti.com/id/public ations/236327/pengajaranapresiasi-nilai-nilai-ceritarakyat-empat-raja-dalampembelajaran-bah 